\title{
Research on Constructing Innovation System of Physical Education in Colleges and Universities
}

\author{
Zhang Jianbin
}

Jiangxi Technical College of Manufacturing

Keywords: Constructing Innovation System, Physical Education, Colleges and Universities

\begin{abstract}
Physical education in colleges and universities in our country has followed the traditional teaching methods and methods. Teachers teach mechanically and students learn mechanically, resulting in students losing their interest in physical education and their teaching effect is not ideal. Constructing an innovation system of physical education in colleges and universities helps to improve students' physical fitness and physical ability so that students can get physical exercise and will-quality cultivation in a pleasant and relaxing environment. This paper analyzes the shortcomings of PE teaching in the current higher education stage in our country and puts forward the method to construct the innovation system of PE teaching in colleges and universities. It is hoped that it can be helpful to the innovation of PE teaching in colleges and universities.
\end{abstract}

\section{Introduction}

Nowadays, the society and economy are developing rapidly, science and technology are continuously updated and updated, and the culture is becoming more and more colorful. This is an improvement of the times and an irreversible trend. These factors determine the higher demand for talent in this era. Such higher education should be nurtured talent should be comprehensive. Education must face the future, so it must be predictable. The long-time examination-oriented education system in our country has a profound impact on PE teaching in colleges and universities. For a long time, students are restrained in the cycle of "learning-test", which is unfavorable to the cultivation of innovative ideas and innovative ideas. The focus of college teaching is exam-oriented education is a long-standing problem that plagues the physical education in our country. It cannot meet the needs of the development of our times and the requirements of the state for the training of high-quality talents and innovative talents by higher education institutions. Future physical fitness of students also requires colleges and universities must have a perfect system of physical education innovation, but also to promote the effective implementation of education, an important way to cultivate the overall quality of students. This article analyzes the existing problems in the traditional college PE teaching mode and puts forward the method to construct the innovation system of physical education in colleges and universities.

\section{The Existing Problems in Physical Education in Colleges and Universities}

In the physical education process in colleges and universities, a large part is influenced by the traditional education mode, and the teaching methods appear to be restrained and unfavorable to students' development. Under the influence of examination-oriented education, colleges and universities cannot correct the educational thought, both students and teachers are in the emphasis on cultural education and neglect the idea of physical education, making the development of physical education difficult. In the teaching mode of physical education, the traditional teaching methods are followed. In the teaching process, the teacher is the center, the main line of the classroom, the implementation of physical education, while neglecting the student-oriented education guideline under the new curriculum standard, which restrains the students The initiative and enthusiasm of sports learning restrains students' interest in sports development and affects the 
cultivation of students in personality, personality, values of life and social adaptability, and the one-sided phenomenon of talent appears.

In the process of PE teaching, PE teaching plan and evaluation is an important part of it. Without a reasonable plan, teaching cannot be better implemented. Without a reasonable evaluation, students cannot master the gradual development of students stage by stage. However, the current physical education program cannot satisfy students' interest in physical education and comprehensive ability. Still the curriculum, semester and school year closely around the teaching of skills and assessment of teaching based on the development of teaching plans and programs. This largely ignores the nature of physical education, cannot make students in physical fitness and sports interests are well trained.

. In the current process of PE teaching in colleges and universities, it basically inherits the traditional teaching mode mainly based on sports technology. In the course of implementing teaching, the teaching method is unchangeable, the machine is stiff and the pattern is serious, making the teaching become boring, lack of freshness and vitality. The teacher mechanically speaking, listening to student machinery, teacher machinery demonstrations, imitation of student machinery, everything has become stiff and lack of vitality. Gradually students are tired of learning sports, and teachers also teach boring. The repetitive teaching method enables students to experience and experience the fun of sports and fitness, and then loses their interest in learning physical education, resulting in the failure to improve the teaching quality and the purpose of teaching.

From elementary school to junior high school, from middle school to high school, then from high school to college, our sports teaching content is always football, basketball, long and short run, long jump. Only in the requirements and standards to improve and change, blindly continuation of the old teaching content, making physical education is not fresh. It has been unable to arouse students' interest in the study of sports. Therefore, it is difficult to stimulate their sports enthusiasm, so that they take the initiative to participate in sports. As a result, you cannot get the desired effect of physical education.

\section{Building College Physical Education Innovation System}

In order to meet the requirement of talents in colleges and universities today, college physical education should recognize the essence of physical education and teaching objectives, change teaching content and teaching methods, innovate physical education teaching plans and evaluation system. University physical education is not only a simple inheritance, but an important platform for cultivating students 'innovative qualities. The innovative qualities of college students mainly include students' innovative awareness, innovative thinking and innovative ability. In order to cultivate the students' innovative consciousness, we must find out the new relationship based on the original knowledge and lead our own sense of innovation. In order to cultivate students 'ability of creative thinking, develop students' imagination, keen observation and unique knowledge structure and inspiration, we must guide, inspire and encourage students to carry out innovative thinking and train students in a democratic and harmonious teaching range Independent thinking ability and open-minded students optimism, improve the ability of team cooperation between students, expand the breadth of student interest and improve the overall ability of students.

Therefore, we must change the current thinking mode of physical education and re-cognize the goals, methods, functions, contents and means of physical education so as to construct a future-oriented physical education teaching system. The process of physical education in colleges and universities is not the process of students to exercise, rely on physical education teaching process is not good student body. The process of physical education in colleges and universities is to train students' awareness of physical exercise, physical exercise habits and the ability of physical exercise, so that students have a basic awareness of physical exercise and attitude, know the importance of physical exercise, so as to cultivate the habit of independent physical exercise know how. The innovation of PE teaching content is to improve students' health needs, meet the development needs between disciplines and meet the future social development needs. Physical 
education teaching in colleges and universities should be added to help to cultivate students' teaching ability of physical education. Physical education in colleges and universities should not neglect the method of teaching in physical education at the same time, strengthen the use of physical education and health methods, the use of physical health maintenance methods to meet the needs of physical exercise, training students healthy and reasonable diet, health habits, Students develop physical and psychological conditioning and other practical health care methods. Physical education theory class should not only give students physical exercise, conservation and appreciation of knowledge, but also imparting a variety of content highly relevant to future society, to find the key link between college sports and social sports, in which theoretical teaching can be ahead of practical teaching , To enhance students' awareness of physical exercise and health.

Modern sports requirements, the theme of the classroom and gradually shift from the classroom to the students, from the past only as the center, to the method, motivation, activity, experience as the center of the transfer, to develop students' ability of independent thinking and innovation. Let students find their interest in exercise learning and find ways to improve their physical activity so as to enhance students' interest in study while emphasizing interactive learning among students and enhancing the awareness of cooperation among students, Interesting teaching, active teaching atmosphere. Guide students to increase awareness of physical exercise. The teaching evaluation system simply based on "result" as the goal of physical education evaluation is not suitable for the present college physical education in our country. It should be transformed from the past results to the combination of modern results and process. The process evaluation plays an important role in PE teaching. It is a feedback link throughout PE teaching. It mainly includes the four aspects of school evaluation, teacher evaluation, student self-evaluation and student mutual evaluation. The process of physical education is to cultivate students' idea of lifelong physical education. Only when the students establish the awareness of physical exercise, acquire some knowledge of physical exercise and develop certain physical exercise habits, can we say that the reform of physical education in colleges and universities has achieved good results.

First of all, physical education must be combined with health education. In order to transform the traditional technology-centered teaching mode into a new way of education that enhances students' physique, learning ability and interest, modern and efficient physical education must combine physical education and health education organically to construct New, to meet the training of students' ability and overall quality of teaching content system. In the new teaching system, the purpose of improving students' system and health is to unify organically the three aspects of psychology, physiology and social health. The cultivation of students' systems and health can enhance their ability to adapt to society and enable them to achieve better development after entering the society. Second, add new teaching content, develop students' sports ability. The new education standard is based on cultivating students' sports ability. Therefore, in teaching content, teachers not only pass on the skills to students, but also attach importance to the cultivation of students' abilities. In the content, add some new projects that can attract students to actively participate in and are willing to participate in, to stimulate their interest in learning, and then learning in sports to improve their own ability and overall quality. Finally, physical education should face the future. In the traditional physical education, it is mainly to solve the sports problems of the past and the present. The future physical education in colleges and universities should look at the future of the physical quality of the students and solve their physical problems in the future, improve their physical fitness and meet the needs of high-quality personnel in the future social development. Only in this way can we improve the level of physical education in colleges and universities to meet the needs of social development.

\section{Conclusions}

Physical education is a complex and lengthy process. Physical education is the beginning of this process. Physical education system in colleges and universities itself is a multi-level, multi-dimensional complex structure, which contains a variety of factors and they are independent and dependent on each other. Therefore, in order to strengthen the system innovation of physical 
education in colleges and universities, it is necessary to start from the practical point of view, dare to find problems, dare to ask questions, and then to solve problems, innovate and think, to improve students' learning ability and overall quality, the quality of teaching, promote the overall development of students.

\section{References}

[1] CAO Yiling. Construction of "Research-based Learning" Teaching Model in College Physical Education[J]

[2] Li Hongqiang. The current situation and prospect of PE reform in colleges and universities from the perspective of humanity[J]. Contemporary Educational Practice and Teaching Research. 2017 (11)

[3] Fang Fang. Incentive-based education in college PE teaching application[J]. Contemporary Sport Science and Technology. 2017 (26)

[4] Han Liu. Reflections on Physical Education Reform in Colleges and Universities[J]. Contemporary Sport Science \& Technology. 2017 (27)

[5] Huang Junyu. Mu class in the teaching of physical education in universities[J]. Sun Yat-sen University Journal (Humanities and Social Sciences Edition). 2015 (03)

[6] Zhou Xiaoxiang, Wu Yinjiang. The status quo and countermeasures of PE teaching mode in colleges and universities[J] .Journal of Jiamusi Polytechnic College. 2017 (10)

[7] Hao Wenbo, Ren Lifeng, Jin Yan. Application of cooperative activities in physical education in colleges and universities[J]. Chinese Journal of Education. 2015 (S2) 